\title{
Parallel narratives: resistance strategies of low-wage female hospitality workers and nineteenth-century black enslaved females
}

\section{Marquita Walker}

\begin{abstract}
This research explores control and gendered resistance strategies of female lowlevel hospitality workers and nineteenth century black enslaved females by linking resistance patterns in historically documented slave narratives with oral narratives of current female hospitality workers. Emerging narratives document parallel stories of oppression, abuse, devaluation, and exploitation and focus awareness on the subordinate position of low-level workers in an oppressor/oppressed relationship. Functioning under two different economic systems, slavery and capitalism, these low-level workers' narratives allow similar patterns of resistance to surface and help us expand our understanding of worker exploitation, female resistance, and narrative as possessing liberatory potential.
\end{abstract}

Keywords: low-wage workers, black enslaved females, labor process theory, resistance strategies

\section{Introduction}

Parallels can be drawn between the resistance strategies to thwart abuse, overwork, and personal indignities currently used by housekeepers in the hospitality industry which mirror female pattern resistance of black enslaved females during the nineteenth century. Situated in Labor Process Theory (LPT), the strategic position of housekeepers within a capitalist system dominated by powerful corporate interests represented primarily by males and black enslaved

This is the author's manuscript of the article published in final edited form as: 
females dominated by white masters under the repressive regime of slavery requires subservient behavior and unquestioned compliance in order to maintain economic viability and personal well-being. Narrative is the methodological tool used to portray the despair female housekeepers and enslaved females feel within their respective positions and desire for a life outside of their current situation. Both use their narratives, oral and written, as forms of symbolic action within specific cultural, historical, and social contexts. I contend the strategic position of subordinate creates a space in which female housekeepers can and enslaved females did, in small and meaningful ways, engage in indirect resistance through passive non-compliance and resist the dominant's exploitation of their working hours, physical and mental well-being, leisure time, self-esteem, and dignity. Linking historical patterns of female resistance to current forms of female worker resistance suggests these strategies are useful tools in preventing females' exploitation in their respective workplaces. Lamphere \& $Z_{\text {avella }}{ }^{1}$ contend women of different racial and ethnic backgrounds with similar work experiences develop similar resistance strategies because of management policies, labor process, and wage structures. By providing a forum in which current workers can discover and share patterns of resistance used against management's exploitation, this research empowers workers to talk about their strategic positions within the workplace and utilize those points of resistance as tools of empowerment in protecting themselves from future exploitation.

The complicated notion of resistance is more than a simple binary between the dominant and the subordinate. Resistance involves power relationships between the powerful and the powerless but also is affected by elements of gender, race, and class, each of which encapsulates social, cultural, and political constructs. Further complicating the notion of resistance is the overarching institutionalized economic structure under which agents and targets functioning 
within different historical time frames engage in the control and resistance tug of war. I utilize the definition of resistance as "an action, inaction, or process whereby individuals within a power structure engage in behaviors stemming from their opposition to, or frustration with, enactments of power. $^{2}$

Control of female bodies, both for labor value and sexual value, illuminates the oppressive nature of exploitation of low level workers including enslaved females and housekeepers in the hospitality industry. According to Foucault, ${ }^{3}$ the body is the primary locus of power over which control is exercised. The use of control mechanisms by those in power, discipline or punishment including the threat or implementation of emotional, psychological, or physical harm, human or technological surveillance, and threats of job loss or reduced compensation are common tactics to manipulate and regulate behaviors in the less powerful. Gordon also recognized that within the body's power relationship lies the possibility of resistance. ${ }^{4}$

Research reveals commonalities in resistance tactics employed by low level workers in multiple venues. For instance, $\mathrm{Ong}^{5}$ focuses on rural Malaysia female factory workers who often feign illness, cry, slow down production, or carelessly assembly components in the production process in response to management's verbal reprimands or other "intolerable demands." This form of indirect resistance is "culturally consistent with their subordinate female status". ${ }^{6}$ Ong posits "modern industrial institutions circulating discourse/practices produce and reproduce, in daily conditions, cultural concepts of male domination and female subordination which are infused into and become the 'common sense' of power relations". ${ }^{7}$ Overzealous management, attempting to increase production, utilize extreme control over female operatives by supervising work routines, restrictions on breaks, communication with fellow workers, absenteeism, clothing 
requirements, and social control by fostering morality through a pseudo-like power structure of village elders designed to command respect and obedience by manipulating emotional appeals to family and workers' welfare. Management's adoption of social control reduces labor turnover and quiets labor unrest.

Ong writes:

As capitalist development reworks the basis of social relations, the changing sense of personhood and of things is most intensively experienced in the realm of production. Sporadic forms of protest, both overt and covert, were not so much informed by a specific class consciousness as by the felt violation of one's fundamental humanity. ${ }^{8}$ The ability of low-level workers to respond to and resist more powerful agents is limited by their placement at the low end of the power structure in economic, political, social, and cultural systems. In the case of black enslaved females, their reactions and responses take place in an informal environment devoid of any civil or legal protections while hospitality housekeepers, as wage earners, respond in an environment mediated by more formal protections such as labor standards, discrimination laws, and rules governing the formation of labor unions. Yet, these legal protections afforded to low-wage workers are, in reality, illusionary protections which do not protect workers but contribute to their exploitation.

Housekeepers are engaged in at-will employment when not represented by a collective bargaining agreement. The at-will contract allows employers to terminate workers at their discretion and allows workers to exit their employment at their discretion. The at-will contract assumes that low-wage workers consent to working for the wages/conditions offered by the employer. If the low-wage worker did not consent to employer stipulations, the worker would simply not accept the job. But there exist huge differences between a worker's acceptance of low 
wage employment and a worker's consent to low wage employment. Low wage workers have few options in the current marketplace. Exiting their current low wage employment means seeking other low wage employment, applying for public assistance if eligible, or having no income. The consequences of having no income are dire and may mean loss of housing, utilities, or personal necessities such as food or medicine, so the options for low-wage workers are minimal at best. The at-will contract for low-wage workers is really only an illusion of choice between equally undesirable alternatives. The freedom of low-wage workers to consent to at-will employment discounts the "impossibility of consent under relationships of domination, subordination, and inequality". ${ }^{9}$ The doctrine of at-will contracts has origins in the Thirteenth Amendment to the US Constitution. The abolition of involuntary servitude in the Thirteenth Amendment is clear, but the mechanisms for achieving that goal fall into two camps: labor markets and commodity markets. Labor markets, based on neoclassical economic philosophy, suggest that an individual bargaining with an employer who fails to "provide workers with the full value of their labor (a commonly stated goal of the Thirteenth Amendment)" ${ }^{\prime 10}$ can terminate his or her employment and find work where his or her labor will be fully valued. The commodity market suggests that labor power has a diminishing return and cannot be saved or stored, so a worker's labor power or ability to produce labor cannot be reproduced for use at a later time. At day's end, that day's labor power is gone because labor power is inseparable from the human mind and body. ${ }^{11}$ Workers must continually protect their ability to produce labor power through "food, shelter, health care, and other necessities". ${ }^{12}$ Therefore, workers face more pressure in continuing their low-wage employment versus quitting their jobs.

Pope explains that low-wage workers stay with an employer because quitting has dire consequences for the worker. ${ }^{13}$ Low-wage workers, often the main support for their family, are 
geographically tied to their locations through community and family networks, cannot liquidate their assets easily, have limited information, and face obstacles in bonding with others like themselves to form collectives. Employers, on the other hand, enjoy huge advantages in access to capital liquidity and information through human resource departments, can easily shift resources from location to location, can easily hire more workers to fill vacant positions, and suffer minimal to no disruption within their own lives when reductions in the workforce occur. "All these factors point toward the inadequacy of individual quits, and none has been satisfactorily answered by scholars of neoclassical law and economics". ${ }^{14}$ The parallels between black females slaves functioning under an economic system supporting involuntary servitude and housekeepers functioning under an economic system supporting the illusion of involuntary servitude suggest these two groups of workers who occupy very similar spaces can and do share similar arenas of domination and resistance.

Gender politics is pervasive within both subordinate groups. The oppression of subgroups of women within their own class, racial group, or culture is predominate in the ways black enslaved females are "dually-oppressed" by their powerful male white masters as well as white women who condemned black women to "dirty work" 15 in order to secure white women's positions as sensitive, moral, and fragile women in the male/female dichotomy, and the way housekeepers are relegated to low paying service jobs in the hierarchy of market transactions and consigned to "invisible" work spaces in the hospitality industry.

Prior to emancipation, black enslaved females toiled as "unfree labor" 16 because the institution of slavery functioned outside the formal labor market. The slave economy reinforced the idea of black women as "enslaved labor"17 both in the home and the community, whose “family responsibilities [were] detrimental to [whites] financial interests". ${ }^{18}$ Consequently, 
slaveholders monitored their workforce by reinforcing a caste system of differences which placed white's material and economic needs above slave women's allegiance to familial duties at their own homes. After emancipation, black females still experienced a racial and ethnic gendered division of labor. Their freedom to participate in the labor market was conditioned by their position as subordinate in cultural, social, political, and economic arenas. Jones writes, "Historic forces ... have shaped the labor patterns of black women at home, in communities, on antebellum plantations, and in the paid labor force". ${ }^{19}$

Female housekeepers in the hospitality industry also experience this racial and ethnic gendered division of labor. Also known as room attendants, room cleaners, maids, or service workers, these low-level workers do the "dirty work" ${ }^{20}$ involved in cleaning and sanitizing rooms, work long hours for low pay, and required to do more with less. Repeatedly undervalued and underappreciated by their employers, housekeepers are among the lowest paid service workers in the hotel industry. ${ }^{21}$ They are primarily women of color disadvantaged within the hotel industry via process and structures dependent on cheap, gendered, segregated, and racialized labor. ${ }^{22}$ In a capitalist economy in which employers squeeze excess value from workers in the name of profit, housekeepers' workloads are increased with little to no extra compensation. ${ }^{23}$ Surveillance of activity and conversations during their work and break time is standard. Housekeepers routinely work "off the clock" in order to complete their assigned duties, suffer personal indignities, and fear reprisal from management for work performance.

These low level workers are invisible to most consumers but very much a part of the global economy. ${ }^{24}$ Large cities become financial centers and "emerge[d] as strategic [regional] territories" which become "concrete operations of the global economy" ${ }^{25}$ which include high paying and highly-skilled jobs in banking and financial services, corporate service industries, 
telecommunications and information flow, and low-wage, manual jobs which support the corporate infrastructure. Those doing business in these financial centers expect the luxuries of home while staying in the cities' hospitality suites, so the importance of maintaining functioning hotels as "a home away from home" is important in attracting business. Hospitality suites literately depend on low level economic workers to provide comfortable and clean rooms, guest services, and amenities to their customers. This polarized dichotomy of wages contributes to the overall disparity in "income distribution and occupational distribution of workers" ${ }^{26}$ Large cities host "the rapid growth of the financial industry and of highly specialized services [which] generate not only high-level technical and administrative jobs but also low-wage unskilled jobs". 27

\section{The Social Reproduction of Labor}

When exploring power relationships in control and resistance dichotomies, Glenn posits the idea of social reproduction as an important concept. Social reproduction encapsulates "activities and relationships involved in maintaining people both on a daily basis and intergenerationally". ${ }^{28}$ Glenn explains the gendered reproduction of labor is the missing link in an integrated model of race and gender which is the nucleus of women's oppression. Domestic labor such as caregiving, childrearing, and household maintenance, historically and predominately performed by women outside of a market structure, freed men to concentrate on paid work within a market structure. The focus of male primacy in the public sphere reified male prerogative in the sexual division of reproductive labor in the home and in the market yet suggested the relationship of women's work to men's work was universal for all women and ignored the racial and ethnic divisions of female experiences. 
As social reproductive labor moved from the household in the early nineteenth century into the public market as a result of industrialization, the term broadened to mean paid or unpaid labor which created exchange or use value in or out of the market. Food preparation, child care, and home maintenance were outsourced to industry and commoditized under a capitalist system which promoted consumption. The division of labor in the reproduction of goods and services to fulfill the needs of the broader population then morphed from household production in which men earned wages for consumption and women provided care for hearth and home to conditions in which most goods and services, (mental, emotional, and educational) are supplied by the private market.

Braverman $^{29}$ notes an "atrophy of competence" in which individuals are no longer able to provide for themselves and necessarily are dependent on the private market to fulfill their needs. The need to provide many of these labor intensive goods and services in the private market such as caregiving, healthcare, food preparation, and hospitality services, and public market services such as protection and welfare require a low-wage labor force disproportionately fueled by racial and ethnic women.

\section{Subjugation of Women by Women}

The nineteenth century's rise of industrialization in the US resulted in a gendered contrast between middle class white women and racial/ethnic women. Middle class white women, responsible for the reproduction of home and family and valued as the moral progenitors of future generations and leaders of reform movements, charitable organizations, and religious renewals, helped enshrine a domestic code which solidified the inequitable gender division of labor among women. ${ }^{30}$ This domestic code allowed white middle class women to maintain superiority over their racial and ethnic counterparts and define themselves as spiritual, refined, 
and intelligent companions for their husbands. ${ }^{31}$ Because the maintenance of superiority in social reproduction required the hard work of cleaning, laundry, gardening, and childrearing, middle class white women established a distance between themselves and their racial and ethnic sisters who performed the dirty work of scrubbing and laundry freeing white women to attend to the managerial duties of the home, volunteer activities, and leisured events. This artificial social and cultural construct allowed white middle class women to avoid the nasty and brutish public sphere in which their fragility and purity would be compromised and encouraged a gender-based division of labor in which racial and ethnic females experienced marginalization in the labor market as well as institutional barriers for upward mobility. White middle class females gained material advantage from their "whiteness" and stimulated pronounced racial and ethnic gendered divisions resulting in different racial experiences for subgroups of females.

\section{Resistance history of black female slaves}

The resistance history of black female enslaved labor was primarily one of covert resistance, but there were instances of overt resistance. To openly resist the master's control meant harsh punishments; enslaved women, punished as harshly as enslaved men, endured whippings and lashings. Some enslaved women might achieve "respite only in return for sexual submission" so a "fine line existed between rape and work-related punishment". ${ }^{32}$ Enslaved women used overt forms of resistance such as "shamming illness and fatigue". ${ }^{33}$ Within the Federal Writers Project (FWP) Slave Narrative Collection are instances when female field workers would rebel against their overseers and strike them with tools such as a hoe; retaliation was usually swift and harsh and often resulted in "rampages of violence that led to the victim's death" ${ }^{34}$ Jones states, "a basic premise of the slave system itself [was] the use of violence to achieve a productive labor force and to terrorize those laborers into a state of compliance". ${ }^{35}$ 
The conditions under which these primarily minority female housekeepers struggle have striking similarities to conditions under which black enslaved females struggled to protect their economic and physical well-being during the nineteenth century. During working hours, the housekeepers' time, bodies, and psyches are controlled by primarily white male members of management who use subtle, and not-so-subtle, forms of coercion, threats, and intimidation in order to extract more work from each housekeeper. Overused, abused, overworked, and fearful of management's retaliation if they refuse to work extra for no pay, endure physical pain from long hours of lifting and bending, and isolation from other workers, the housekeepers simply expend extra energy in meeting management's demands in order to retain their positions. They work through their breaks, stay late after shifts to "finish up" a room, refrain from drinking liquids which require bathroom breaks, and perform extra duties such as cleaning up to thirty rooms per shift, change the "heavenly beds" which require fourteen pieces of linen and pillows, and push a 300 pound amenities cart over carpeted hallways. Management's demands exact a toll on their bodies and minds and result in increased physical and mental injury, decreased leisure time, and loss of dignity.

Hotel housekeepers are an unseen workforce who remain in the background and have little interaction with hotel guests. Sometimes called back of the house people "who are hidden from view", ${ }^{36}$ housekeepers keep the hotel running smoothly. Without them, the hotel industry could not function. This important component of the workforce receives little pay, few benefits, little recognition, and no respect. The hotel, an economic space in which production and consumption take place, contributes to the difficulty in organizing housekeepers because of this division of front and back labor. 
The exploitation of women, not a new phenomenon, is particularly pronounced within the hospitality industry. Housekeeping, by its nature, is actively associated with women as caregivers. ${ }^{37}$ The very process of "feminization devalues work roles"38 because feminization implies a sexual undercurrent which reinforces a subservient position. ${ }^{39}$ The role of female housekeepers as “invisible workers” increases their vulnerability under management's control. An integral part of the workforce, they are considered easily replaceable because of the low skilled nature of their job. Often working in isolation, housekeepers are required to comply with their supervisor's orders without objection. The domination and harassment by management to which housekeepers must submit engenders a sense of anger and resentment which is channeled into forms of subtle, covert, or overt resistance. ${ }^{40}$ Because outright resistance such as insubordination, work stoppages, or property damage would result in termination, housekeepers find covert ways to resist management's demands. Gabriel describes this phenomenon as a way to "maintain self-esteem, gain emotional gratification, attain a sense of self-control, and assert the self as a meaning-making agent in a world of (more powerful) others". ${ }^{41}$ The "invisibility of resistance does not necessarily imply the absence of resistance". ${ }^{42}$

Explorations of the multi-faceted ways in which housekeepers resist or fend off management's requests to work without pay, protect their leisure time, and protect their bodies and minds are similar to the resistance black enslaved females employed against their white masters in "attempts to resist sexual compromise and permanent enslavement" ${ }^{43}$ The hidden history of black working class resistance expands as working class consciousness becomes prominent in historical and scholarly writings. Harley writes:

It should not be surprising that African men, women, and children survived in the face of unrelenting work demands, humiliations, and the threat of and actual sexual assaults of 
enslaved women and girls that characterized the system of chattel slavery practiced in the United States". ${ }^{4}$

The despair engendered by chattel slavery created a space in which enslaved females could sometimes subtlety "resist" owners' demands. After slavery was abolished, this resistance became a basis for oppositional tactics such as refusing to work, voicing opposition, or participating in boycotts and strikes. Harley writes:

The strategies of resistance utilized by black wage earners ranged from refusing to perform certain tasks to engaging in work slowdowns, speaking their minds (to the point just short of being fired), abruptly quitting, refusing to 'live in,' 'blacklisting' the most egregious employers, and stealing (i.e. supplementing their low wages by taking more food than employers intended)". 45

Similarly, management's ultimate control over housekeepers creates a sense of despair from which housekeepers mount oppositional tactics such work slowdowns, voicing opinions, and organizing.

\section{Theoretical Foundation for Research}

Situated in Labor Process Theory (LPT), this research explores the control and resistance dichotomy between enslaved females and their white masters under the economic system of slavery and hospitality management and labor in a capitalist free market system in two large Midwest hotels. LPT explores the systematic deskilling of the workforce for the purpose of increasing production and profit for owners of production and "examines the labor-capital conflict over control of the labor process". ${ }^{46}$ An extension of Marxist theory about work organization, LPT explores the control and payment of work, the skills necessary for work, the facilitation of work, and workers' resistance mechanisms. Under the competitive system of 
capitalism, the owners of production water down workers' skills thus reducing workers' pride, sense of worth, and power over their work and then use this deskilling as the reason for cutting workers' wages and increasing workers' hours. ${ }^{47}$

Workers, under capitalism, are subtly co-opted into producing excess labor by embracing capitalism's fundamental notions which in essence constrain them. ${ }^{48}$ Surplus labor blurs the lines between the reproduction of labor power and sustenance (necessary value) so workers are unaware when necessary labor ends and surplus labor begins. ${ }^{49}$ Acting under the illusion of choice, workers work for their own exploitation. An investment in and expansion of scientific management practices "promote[d] resistance and struggle and in so doing undermine[d] the extraction of surplus [labor]" ${ }^{\prime 50}$ which provides the profit margin for capitalists. Management's control of the work process "presume[s] that capitalist social relations are 'antagonistic' 51 resulting in a win-lose situation in which gains for management are losses for labor. Benson concurs that workers are restricted by their work culture and adapt to and resist these constraints. $^{52}$

Hochschild ${ }^{53}$ and Brook ${ }^{54}$ suggest labor power is an aggregate of physical, mental, and emotional labor in varying degrees and situations from which emotional labor cannot be divorced and that workers have no control over their emotional labor within the context of the employment relationship because a worker's aggregate labor power is a package with "shifting boundaries at the "frontier of control'". Workers are constantly functioning within an antagonistic organizational framework under the "predominance of managerial control". 55 Therefore, "once labour power is commodified, albeit within a contested context, workers no more retain ownership or predominant control over the form, timing, and use of their smile, than they do the dexterity of their hands or the mental-moves required in their jobs". ${ }^{56}$ Brook's 
observation aligns with Buroway' ${ }^{57}$ notion that workers' consent in the labor-management relationship actually contributes to the worker's own exploitation while other scholars observe the marginalization of female workers by management and labor collectives and "how workers are persuaded to release their labor power". ${ }^{58}$

Bolton, on the other hand, posits service workers within a commercialized arena are aware their emotional labor impacts their work lives and use their ability to expend or withhold emotional labor to "disrupt the carefully preserved emotional climate of servitude" ${ }^{59}$ Workers choose how much emotional labor to invest in interactions with customers and management based on the context and motivation of the interaction. Therefore, service workers retain and manage some control over these commercialized interactions and use this space to resist management's control. Bolton suggests interactions outside of the commercialized arena are free from managerial control thus giving the worker more freedom to express his or her own truth. ${ }^{60}$

Hochschild explores the idea of community among service workers as a form of resistance in her study of flight attendants who provide emotional support for each other when dealing with unruly customers yet are restrained by management's entreaty to maintain decorum among fellow flight attendants. ${ }^{61}$ Korczynski ${ }^{62}$ further explored the concept of "collective emotional labor" ${ }^{33}$ by suggesting service workers form informal "communities of coping" 64 which act as "a curious mixture of consent and resistance to work". ${ }^{65}$ His findings suggest consent strategies served as an outlet relieving workplace tensions in call centers and concluded some workers formed communities of coping for "collegial support" 66 and/or shields from customer abuse. Communities of coping acted as resistance strategies as workers shared negative feelings about customer interactions when management wanted only positive interactions shared. Management's efforts to introduce a culture of service in the call centers were thwarted as 
workers actively resisted by "shar[ing] antipathy toward the customer" ${ }^{67}$ thus making direct management intervention and workforce control more difficult.

The concept of resistance within LPT is a useful tool in exploring how housekeepers' bargaining power, diluted by management's strategies of exploitation, breeds spaces of resistance to react to, engage with, and counter management's control of their work lives and bodies. In resistance literature, the terms strategies and tactics "emphasize[s] the simultaneously positive and reactive nature of resistance". ${ }^{68}$ Workplace resistance takes the form of "small-scale and informal means by which workers counter managerial control of the workplace" ${ }^{69}$ Housekeepers continually reconstruct their relational and contextual identities based on the situational environment, their expected roles, and preservation of their dignity by negotiating their position with management in subtle and covert ways. ${ }^{70}$ Understanding theories of resistance helps contextualize subtle and covert actions in which female housekeepers engage on a daily basis. ${ }^{71}$ Foucault suggests "where there is power, there is resistance" 72 and that "resistance is embedded within discourses and interactions". ${ }^{73}$ The malleability of LPT to address the changing resistance/control dichotomy of service workers allows us to reconceptualize the space in which housekeepers and enslaved females mediate their physical and emotional labor in resisting management's demands.

\section{Methodology}

This research explores the oral narratives of housekeepers in two downtown Midwestern hotels as they in engage in resistance through union organizing and the slave narratives of enslaved females in nineteenth century. Similar themes of resistance resulted from a content analysis facilitated through axial coding of transcribed notes I took during interviews with organizers and housekeepers involved with The United Needle Trades Industrial Employees 
(UNITE) and the Hotel and Restaurant Employees (HERE) (UNITE-HERE) as well as female slave narratives garnered from historic and scholarly works. An analysis of the collected data reveals themes of resistance which allow housekeepers to negotiate and mediate their work environment while simultaneously attempting to organize. These themes are similar to resistance themes emerging from an analysis of female slave narratives.

\section{Data Collection}

In collecting data concerning housekeepers' resistance strategies, I attended several monthly organizing meetings held in 2011 by UNITE-HERE in order to meet organizers and service workers interested in unionizing. Fifteen to twenty workers attended these various meetings, and I was able to build a relationship with three of the female housekeepers and one male worker, known as a floater, who agreed to be interviewed; the male worker's interview is included in order to emphasize the despair and desperate working conditions housekeepers endured. One-on-one individual interviews are conducted in a downtown coffee shop to allow respondents freedom from possible workplace retaliation. Using open ended questions pertaining to their experiences with organizing, the demands made on them during their work day, and their responses to those demands, I took notes which were later coded for emerging patterns which yielded themes of resistance strategies; these strategies were compared to themes emerging from slave narratives.

Data concerning female slave narratives was garnered from a Google Scholar search using the keywords resistance, slave narratives, female, and oppression as well as scholarly works in the Federal Writers Project Slave Narrative Collection. These narratives were mined for more scholarly works, and all narratives were coded for emerging patterns yielding themes of resistance strategies which were then compared to housekeepers' narratives' themes for 
similarities. According to Riessman ${ }^{74}$ coding is necessary to uncover a text's meaning. Narrative analysis requires the process of coding in order to categorize textual units, words, phrases, or sentences, into broader categories which reflect patterns or themes within the text and find meaning within the narrative. ${ }^{75}$

\section{Data Analysis}

The assumption associated with narrative analysis is "that storytelling serves the purpose of creating meaning from one's lived experiences" ${ }^{76}$ This means narrative analysis is particularly suited to oral and written narratives from low level workers who share stories of lived experiences, current and past. Paul Ricoeur ${ }^{77}$ describes the process of text interpretation by differentiating between understanding text and explaining text. He argues that understanding text "is about grasping or getting a feel for the whole chain of seemingly fragmented meanings... [or] finding the meaning of the text" ${ }^{78}$ while explaining uncovers the structural relationships within the text. Consequently, my transcribed notes were mined for similar words or phrases which were grouped into broader categories from which three similar themes of resistance emerged: resistance through narrative, resistance through pain, and resistance through collective backing. Axial coding allowed me to directly focus on the texts and identify important aspects.

\section{Findings}

\section{Resistance through narrative}

Narrative can be used to dominate, oppress, or liberate. Abusers require a conspiracy of silence to enforce their rule and to protect their name. ${ }^{79}$ Before the oppressed can tell their story, a claim of truth is necessary. Current documentation via news and media reports about the plight of hospitality workers does not reflect the depth of the chasm between labor and management. Only personal stories bring to light the pervasiveness of management's abuse and disrespect of 
housekeepers and portray the human side associated with low wage work often missing in the efficiency model of labor versus management. Exploring the lived experiences of housekeepers is a necessary precursor in detailing the rationale for continued resistance strategies.

Marta, not her real name, a housekeeper at a large downtown Midwestern hotel, shares her story of frustration and discontent. Taking the bus to and from work, Marta cleans 18 rooms per shift depending on whether the rooms are "check outs," overnight guests leaving the hotel, or "stay overs," guests remaining at the hotel for consecutive nights. No mops or buckets are provided as cleaning tools; all rooms are scrubbed on one's hands and knees. Marta is 28 years old, African-American, married, physically fit, and has worked at the hotel for four years. Her starting wage of $\$ 7.50$ per hour is now $\$ 9.00$ per hour. She sometimes receives tips, has no health insurance, and never works over 40 hours per week. Marta defaulted on a student loan when her husband lost his job because she could not maintain the full load required by the loan and work the hours necessary to pay her family's living expenses. The loan was garnished from her work wages. ${ }^{80}$ Marta falls into the category of the working poor, those who make wages lower than $\$ 20,000$ per year.

Marta engages in resistance through union organizing and hopes that UNITE-HERE, attempting to organize the housekeepers, is successful. She knows hotel management is aware of her union activities and constantly anticipates repercussions for her activity. She carefully complies with management's requests in her daily work activities and doesn't "agitate" during working hours. She hopes her "legal" resistance will eventually allow her to work in a unionized environment which would afford protections like better wages, job security, and a voice in the workplace. She cannot quit her job at one hotel and move to another hotel in the downtown area because hotel staffing agencies refuse to hire workers who have previously worked at a rival 
hotel for one year. The downtown hotels report no policy prohibiting the hiring of full-time hotel workers from one hotel to another exists; antidotal evidence from hotel workers trying to transfer to other hotels suggest otherwise.

Betty, not her real name, an unassuming grandmotherly type, shares her story as a housekeeper at a major downtown hotel for the past 30 years. She is one of four housekeepers hired by the hotel; other housekeepers are subcontracted through a staffing agency. Betty is African-American, married, and has grown children. Betty comes to the Midwest from the Deep South as a teenager, works from 3-11 pm, is responsible for putting up, getting out, and changing linens on around 25-30 roll-away beds per shift, responding to guest calls for amenities, problems with rooms, and the "turn down," a VIP amenity in which she turns down the covers on the bed and places a mint on the pillow. Betty's father instilled in her a work ethic which involves doing one's best under all circumstances. She carries out that work ethic in her daily routine by always doing her best and keeping busy even when she feels bad. There is some evidence the personality trait of hardiness helps to moderate workplace adversity through a belief one has some control over events and outcomes and that one can grow from positive and negative experiences. ${ }^{81}$ She relies on faith and prayer to get her through days which aren't going well. Giordano stresses the importance of having an "anchoring force" in life. ${ }^{82}$ Also important is 'a belief system that provides meaning, a cohesive life narrative, and an appreciation of the uniqueness of oneself". ${ }^{83}$ Her concerns center on issues of guest comfort, room cleanliness, and coworkers' welfare.

Betty relates more duties have been incorporated into the housekeeper's daily responsibilities. Initially housekeepers cleaned 15-16 rooms per shift and now clean 30 rooms per shift. Management began a program called "Refresh," or freshening up a room in which a 
guest spends more than one night. The Refresh program gives surface attention to the room such as picking up wet towels, restocking amenities, emptying trash, and wiping down counters; it is presented to guests as an environmental option which saves the earth's resources. Guests "choose" the Refresh option by placing a brochure/hangtag touting the wise use of the hotel's resources on the door; this frees up housekeepers to clean more rooms per shift because of the abbreviated nature of the refresh.

Management relies on Betty to settle guests' room complaints because she has a natural rapport with guests and always views their concerns as being right. She tells of one supervisor who said he wished he had her ability to settle guest complaints. She reasons guests pay a high premium for staying at the hotel and should receive quality service. After thirty years of service, Betty makes $\$ 11$ per hour, has four weeks of vacation, six paid holidays and one floating holiday (her birthday), and 12 free nights at chain hotels across the country. Most housekeepers, Betty relates, can't take advantage of the free hotel nights because so few are able to travel for vacations or holidays, so this benefit aids very few housekeepers. Available overtime opportunity is taken by the same volunteers, though management does run a seniority list.

Betty was instrumental in bringing attention to the housekeepers' plight through UNITEHERE. She speaks to groups of concerned citizens about the abuse and overwork housekeepers endure simply to keep their jobs and has been interviewed by local newspapers and one national magazine. Because of her spotless work record, good work ethic, her ability to deal with guests, and her long tenure at the hotel, Betty feels management fears retaliating against her. She is very careful to always fulfill her duties and never give management an opportunity to discipline her because she knows of management's constant surveillance. Her preference for unionization as a 
resistance tactic makes friends and enemies within the housekeeping staff. Housekeepers fearful of losing their jobs because of union activity shy away from Betty.

Miguel, not his real name, is Latino, male, 30 years old, and has a work visa. His job as a floater means he covers worker vacancies; he worked at four of the downtown Indianapolis hotels through a subcontracting firm known as Hotel Hospitality Services (HHS). He first worked at the Marriott for three months as a houseman, a job in which he pre-cleaned rooms by stripping the room of dirty stuff such as bed sheets and trash. He is responsible for four floors; there are three housekeepers per floor who clean 20-30 rooms per shift. Miguel shares:

It was a very high paced job; I had to deal with housekeepers who had a difficult time cleaning rooms because of difficult guests who would leave the room particularly dirty. Not enough time to clean and no overtime, some housekeepers would come in early to fill their carts with towels and soap in order to get work done. Housekeepers were afraid of bosses so they worked off the clock. Bosses would humiliate the housekeepers. One housekeeper came to me crying because she couldn't get the room done quickly enough. She was tired and begged me to help her with this. She said I need to get this done or I'll be fired; they belittle people. The boss told her "why don't you get the room done; you're way behind. Do you want to get fired?" She came to me crying. This was heavy on her shoulders.

The managers are driven by the big bosses; the faster they make the crew work, the bigger the bonuses they get. A lot of times, the manager will use an employee against another employee. They belittle employees and say, "How come you can't get the room as fast as this person." They humiliate housekeepers by posting on a bulletin board 
outside management's office the percent of rooms cleaned by each housekeeper each day. To get $100 \%$ meant cleaning $20-30$ rooms per day.

It is difficult for housekeepers to say anything because over half are undocumented and work through a temp agency and are afraid to say anything. They suffer more pressure and more humiliation from bosses; bosses want to get the job done and save money. I see the hotels tend to hire temps because they don't have to pay benefits and are not liable if something happens to the housekeepers. If you work directly for the hotel, it is better.

One day I was supposed to be out by 5 and it was 5:30 before I got out, because I was filling sheets, materials for cleaning. I got into the elevator and my boss was there and he said "Miguel, what are you doing here? My boss was from Peru. He said "you were to leave at 5; not understanding, I told him I was sorry and was told if it happened again I would be terminated. Paychecks were short; I was missing 1-2 hours every week; I would report it and they told me it was probably mistake in system but I never got the money. All checks were also short; I eventually got the money through the lawsuit.

Miguel was part of a lawsuit for wage theft filed by 16 low-wage workers from the Marriott and Hyatt hotels against HHS in January, 2012. The lawsuit was settled in December, 2012 with the plaintiffs receiving satisfactory back wages ${ }^{84}$ Many employees chose not to participate in the lawsuit fearful management would recognize them and retaliate against them. Miguel said the hotel reduced his hours to one per week, so he left.

It wasn't worth my time to work one hour each week. UNITE HERE offered me an Organizing Beyond Barriers (OBB) summer program to train workers to be organizers. I 
did the program and at end of program received a stipend, and eventually went to work at the airport in a restaurant represented by the union.

Miguel's mother also works as a housekeeper at one downtown Indianapolis hotel. She tells him how she's mistreated and asks him how bosses can expect her to work so hard for so little money and no benefits. He wonders how he can make an impact to make things better.

Narrative can take the form of "grumbling, gossip, or rumors against management" 85 or stories. Grumbling conveys a general sense of discontent about workloads and pains within the subordinate group and allows housekeepers a release mechanism for pent up frustrations which may later result in bigger outbursts of anger. ${ }^{86}$ Gossip as resistance represents a "safe social function" 87 allowing housekeepers to talk about job changes or problems and circulate information about management's directions or restraints without being labeled an instigator or troublemaker while disavowing personal responsible for the gossip. Aware of management's constant surveillance of their activities, the gossip mill becomes an information conduit allowing negotiation of rumors against management, modifications in work responsibilities, and impact assessment of those changes on their time and bodies. This assessment can lead to future forms of more overt resistance such as stories or organizing.

Stories, also a powerful narrative form, allow housekeepers to share experiences and vent frustrations. Stories convey a deeper sense of despair and permit eruptions of candor and outspokenness often tamped down within the work environment. Stories showcase adversarial relationships between housekeepers and supervisors through examples of wage theft, discrimination, and harassment. Narratives from personal experiences are powerful weapons in bringing awareness to housekeepers' oppressive work environments and serve as a catalyst for 
stronger forms of resistance such as eliciting collective backing, work slowdowns, and organizing.

The similarities between the housekeepers' oral narratives parallel the stories told within written slave narratives. The concept of self and other within a specific culture plays an important role in the stories of housekeepers and enslaved females. A "conflicted sense of self" 88 arises where white dominate culture prevails. In both worlds, cultural sanctions against public displays of activism exist. During the nineteenth century's cult of true womanhood, females were socially prohibited from public activism, while currently direct public activism, though legally protected, is discouraged in favor of more nuanced and sophisticated activism through negotiation or mediation. Both enslaved females and housekeepers are subjected to abuse through a system of legal discourse. Both explicate the oppression and repression females feel in male-dominated roles and provide examples of the powerlessness of the subservient role.

Slavery narratives appeared in a culture which did not recognize female slaves as persons. "Middle-class gender norms that were the guiding principles of the nineteenth century 'cult of domesticity' were unattainable for the enslaved and most free (and newly freed) African American women and men". ${ }^{89}$ Being black, female, and a slave equated with being a nonperson. Both narratives portray the despair housekeepers and enslaved females feel within their respective positions and desire for a life outside of their current situation. Both use narratives as forms of symbolic action within specific cultural, historical, and social contexts. Each female, with her own personal challenges, constructs of self, and literary abilities, fashions her narrative within her respective repressive and oppressive situation. Housekeepers seek to free themselves from the oppressive bonds of management's monopolistic hold over their economic lives, and black enslaved females sought to free themselves from the repressive physical and psychological 
bonds of slavery. Both try to come to terms with their situations via narrative which gives "expression, shape, and significance to those conflict[s]"90 through forms of resistance. To ensure the truth of their stories to audiences, black enslaved females, as non-persons, established their existence by signing their narratives "written by herself" to confirm the narrative was written by the slave and not a white literate.

Workers' and slaves' narratives use critical literacy to break free from an oppressive "culture of silence" and transform the structure of oppression. The very act of narrative speaks to the idea of a relationship between literacy and sub-humanness. Slaves were thought to be an inferior species, an other, whose inability to read and write relegated them to a powerless position. Proslavery forces created systems of education, documentation, mobility, and dress designed to enable whites to "tell the difference between enslaved and free black[s]"91. Yet some slaves were able to manipulate these restrictions as documented by the autobiography of Mary Prince, a slave in the British West Indies, who, through writing surrogates, wrote and published The History of Mary Prince and uses language which "contradicts the stereotypical portrait of the ignorant slave for her text is linguistically rich". ${ }^{92}$ Narrative is liberating, and silence and repression [are] enslaving". ${ }^{93}$

The workplace culture which represents oppressor and oppressed creates a space in which workplace adversity festers and chafes. Excessive workloads, lack of autonomy, and fear of retaliation increase tensions between labor and management. The oppressed develop resilience, the ability to positively adjust to adversity and oppressive tactics by developing problem solving skills ${ }^{94}$ and learned hardiness. ${ }^{95}$

\section{Resistance through pain}


The pain from job injuries can be used as a form of resistance against management's increased pressure to perform more work in a shorter timeframe. The issue of increased injuries resulting from pressure to work faster and harder to achieve an output goal fortifies the argument that housekeepers need protections in the form of a collective such as labor union, work council, worker association, workers' rights' legislation, and judicial decisions which safeguard worker safety, health, and dignity in order to mediate work speeds, limits on lifting and pushing requirements, provision of protective clothing or gear, and protection from chemicals or carcinogens used in cleaning.

The increasing workload results from the pressure large hotel chains exert on the housekeeping staff to satisfy guests' needs and operate on economies of scale which increase short-term profits. ${ }^{96}$ For example, in 2006 , one Hispanic female housekeeper, a 10-year employee working for a Midwestern downtown hotel was struck by a chair in the groin while setting up a banquet. Bleeding and in pain, she reported the injury to her manager who told her, "This kind of thing happens to you every month down there, so just put a towel on it and get back to work". ${ }^{97}$ Quigley writes a coworker took her to the hospital where she received stitches and a bill for $\$ 1,400$. She was off work for five weeks. Most housekeepers at the downtown Indianapolis hotels are subcontracted through Hospitality Staffing Solutions (HSS). ${ }^{98}$ Quigley reports HSS refused to pay the bill. Earlier in 2012, the Indiana Department of Labor fined HSS and a major downtown hotel more than $\$ 50,000$ for violations of the Indiana Occupational Safety and Health Act (IOSHA) for failure to train housekeepers on the proper handling of chemicals, blood, and blood-related needles encountered during their cleaning duties and failure to provide IOSHA worker injury records. This instance of management's blatant disregard for a 
worker's physical pain became part of a large collection of worker stories used to frame the public debate about on-the-job abuses housekeepers suffered.

Injury rates for hotel workers are higher than for any other service section. ${ }^{99}$ Age, being female or Hispanic, job title, and company were all independently associated with injury risk. ${ }^{100}$ The extent of housekeepers' injuries is probably understated because the Department of Labor Statistics doesn't capture data about occupational injuries for single occupations. A 2006 National Institute for Occupational Safety and Health study determined housekeepers had the highest injury rate of musculoskeletal disorders (MSDs) defined by the Bureau of Labor Statistics "as injury or disorder of the muscles, nerves, tendons, joints, cartilage, or spinal discs”. ${ }^{101}$ Acute trauma cases include contusions, fractures, lacerations, heat burns, and sprain or strain injuries with evidence of an injury mechanism that involves acute contact with outside objects (e.g., hit by, struck against) that were not otherwise categorized as an MSD. ${ }^{102}$ Female housekeepers had about three times the risk of injury than male housekeepers, and Hispanic housekeepers were 70 percent more likely to be injured than white female housekeepers. ${ }^{103}$

Slave narratives also document pain as resistance. Mary Prince's autobiography chronicles her suffering and use of pain as a form of resistance to refuse the demands of plantation work. Baumgartner writes, "The slave's broken down body [which] would normally be construed as a sign of slavery's power to debase, mutilate, and destroy, ironically serves the key locus of opposition enabling her to refuse to capitulate to further demands of servitude". ${ }^{104}$

Prince relates horrible working conditions in which resistance would exact extreme lashings, deprivation, and brutality. All energy is consumed with efforts to stay alive. When sold into a less beastly work environment, Prince is able to use her pain as a "central site of resistance" within the master-slave relationship by "deploying, interpreting, and appropriating her 
body for her own purposes". ${ }^{105}$ After years of overwork, cruelty, and abuse, Prince uses her own agency to manipulate and exert some control over her own willingness or refusal to work by "explaining and defending her inability"106 because of her "lameness, skin inflammation, painful and swollen joints and 'rheumatism'". ${ }^{107}$ As her master's property, this form of resistance could have economic and political repercussions because she does not have rights to her own body. If unproductive, her owners could sell her or worse. These covert and cryptic forms of indirect resistance are difficult for slave masters to document, and Prince was able to utilize "indirect methods of resistance in order to obtain personal relief from lifelong, backbreaking labor and/or to sabotage the goals of the slave owners". ${ }^{108}$ Prince uses her pain as a "protest against the demand to perform ... [in which the sufferer] uses her body (and its sufferings) to communicate with and influence her social world"109 and draws upon "cultural resources to transform [her] own victimhood and articulate new models of self and society". ${ }^{110}$

Brodwin suggests illness complaints "are meant to arouse a response in audiences, as well as express discomfort". ${ }^{111}$ Occurring within cultural frameworks, these actions shape lived experiences and are constrained by authoritative power relationships. Brodwin also suggests chronic pain carries with it a performance by an agent or actor suggesting the pain has some voluntary aspect; many scholars disagree that pain has its own "agency and volition". ${ }^{112}$ Scott recognizes resistance takes the form of insubordination through "speech or act for subordinate groups" and "transforms the self". ${ }^{113}$ Kleinman writes "bodily complaints could also be interpreted as a form of resistance against local sources of oppressive control". ${ }^{114}$ Pain as resistance refashions the work landscape into a more palatable environment where females can ease or eliminate their suffering by avoiding or mediating the source of their pain ${ }^{115 .}$

\section{Resistance through collective action}




\section{Community backing}

Collective action in the form of community support for the housekeepers was built through the efforts of Hotel Workers' Rising, a national organizing campaign conducted by UNITE-HERE, which employs multiple tactics in their organizing drives. The campaign built a sympathetic network of community activists by creating an assemblage of prominent women in the community who understood the housekeepers' concerns and apprehensions about their safety, health, and dignity because they shared similar perspectives of oppression and repression and were able to voice their concerns to a broader audience through speaking engagements, support groups, and media attention. This public pressure on hotel management emphasized more sensibly restructured housekeeping work assignments resulting in less work intensification while still maintaining the quality of services and a competitive edge in the market.

This concern and collective backing resembles the support Northern women who were, during the abolitionist movement, largely "leisured middle-class" women. During the nineteenth century, these women championed the anti-slavery cause as a "matter of conscience that overrode convention" and felt some responsibility for the elimination of the repression and oppression of chattel slavery. ${ }^{116}$ They encouraged women to read the Bible and slave narratives to educate themselves on the "abominations of slavery." 117

Slave narratives evolved from ex-slaves accounts of abuse in conjunction with the writings of white women whose "developing feminism was patterned upon abolitionism". ${ }^{118}$ Antislavery texts featured the abusive relationships endured by young female slave mothers and children and brought to the public's attention images of sexual abuse and child labor. White Northern women's engagement with and attention to slavery brought an emotional aspect to the story and empowered white women to act as power brokers for their powerless sisters. 
Because the drastically changed nature of the worker/employer relationship over the past few decades, past resistance strategies such as firm or industry specific workplace organizing via labor unions are less effective in protecting low wage workers' economic and personal concerns because of employer resistance to organizing and weakened laws concerning workers' rights. The gendered, ethnic, racial, and immigrant makeup of the low wage workforce in the hospitality industry introduces complicated issues such as legal documentation which adds a dimension of uncertainty to the workers' employment status. Low skill levels and oversupply in the labor market also complicate an individual's ability to force economic changes in the employment relationship, but collectively low wage workers can leverage political power by impacting public policy through the mechanism of community unions. According to Fine ${ }^{119}$, low wage workers have more political power than economic power so moving the locus of organizing outside the workplace and into the community allows geographic enclaves of low wage workers a space in which an emphasis on work, housing, healthcare, and educational issues are equally addressed. Shifting organizing into the community and home becomes more relevant to the worker who is working multiple jobs and simply doesn't identify with a single workplace. ${ }^{120}$ Community outreach centers, sometimes called community unions, are more successful at improving low wage workers' wages and working conditions through public policy changes than through interventions in the labor market. ${ }^{121}$

\section{Legislative efforts}

Collective action as a form of resistance includes strategies to pass local legislation protecting housekeepers' rights in securing employment and tax benefits. For instance, a boycott, in response to injuries and injustices suffered by its housekeeping and restaurant staff, of one downtown hotel was honored by a large religious convention, a state legislative caucus, and the 
National Football Players Association from 2010-2011, and predated a global boycott. In 2011, the local city council introduced a county tax rebate ordinance for hotel workers amounting to \$200 per year. Supporters of the ordinance, carrying signs which said "Give 'em a break", filled the assembly rooms and flowed into the streets during public hearings. The crux of the debate pivoted on tax increment financing (TIFs), touted as necessary to bring good paying jobs to the city. The tax relief was to be funneled into downtown hotel development, convention and tourism management, and city redesigns to attract tourists. Since the very life blood of the hotel industry relies heavily on its housekeeping staff, the small tax relief for housekeepers seemed only fair in light of the money poured into the hotel and convention industry. Yet, the council members voted down the ordinance along party lines citing expanding operating costs during an economic downturn as the reason.

Another local council attempt was to "outlaw" a one year prohibition against hiring housekeepers who leave one downtown hotel and try to gain full-time employment at another downtown hotel. Tantamount to "blacklisting" workers from employment, hotel management denied such a policy existed, but hotel staffing agencies subcontracted by hotels to hire, fire, and manage hotel operations, engage in this practice. Antidotal evidence from workers applying for positions with downtown hotels reflects they are being turned away from hotel jobs because of this unwritten but enforced policy. This policy has a devastating effect on workers wishing to change jobs within the hotel industry. The legislation was voted down along party lines, reintroduced in a subsequent session, passed, and then vetoed by a Republican mayor who stated there was no compelling evidence that blacklisting existed.

Collective forms of resistance underscore the devalued and underappreciated status of housekeepers. Utilizing space between resistance and compliance, housekeepers and their 
supporters attempt to resist management's encroachment on their economic and physical wellbeing much as did Northern women during the nineteenth century who fought through public displays of support and anti-slave narratives to give value to their oppressed "sisters" in slavery.

\section{Suggestions for resistance strategies}

\section{Individual resistance}

One of the most difficult tasks for an individual low wage housekeeper in a precarious employment relationship to achieve is to confront management with grievances or complaints. Worker protections are few and the likelihood of discipline or termination is ever present. There may exist some avenues of individual resistance in the form of relationships formed among and between housekeepers working in the same hotel. The National Labor Relations Act protects concerted activity by two or more workers who believe they have been unjustly disciplined. Though the initial complaint may result in discipline up to and including termination, the aggrieved workers do have recourse to file suit with the National Labor Relations Board which may support their case. The resolution time in these cases is usually very long and often discourages low wage workers from pursuing this avenue.

An important avenue of individual resistance is to document management's demands to work in unsafe conditions such as working without protective clothing while exposed to chemical or biological hazards such as solvents which contain pesticides or coming into contact with contaminated waste such as human excrement or hypodermic needles when cleaning rooms. Incidents of psychosocial hazards such a bullying, stress, and violence should be recorded as should injuries and pain associated with the daily monotonous and repetitive labor intensive movements such as lifting mattresses to change bed linens, lack of proper cleaning tools, and working off the clock. Building a record of work-related abuses can be used in constructing a 
case against management which documents methodical harmful activities in which workers are obligated to engage.

Because the nature of housekeeping in the hotel industry requires individual housekeepers be dispersed in different rooms for cleaning purposes, their personal safety and wellbeing is compromised through isolation. If injured, assaulted, or harmed in any way, the response time for help may not be immediate. If all hotel housekeepers were equipped with some sort of device or alarm which could be easily accessed, much like the lifelines provided to the elderly in case of a fall, their plea for assistance could be more readily answered thus reducing response time for help and potentially decreasing time spent in harm's way. This solution not only alleviates the fears housekeepers might experience from working in isolation by decreasing their anxiety, pain, and suffering, but potentially could decreases the firm's lost-time accidents and insurance costs. The initial investment in the devices or alarms would be minimal and easily offset by the increase in long term profits.

\section{Collective resistance}

In order to mediate the model of the standard employment relationship in which tension between employers and employees within the rigid institutional structure of the workplace pits labor against management, policy changes must occur. The possibility exists that continued pressure by low wage workers through community unions and the coalitions they build with faith, civic, and ethnic and racial organizations could put pressure on elected officials to move toward policies more beneficial to low wage workers in workplace and community arenas. Though not rising to the level of a national social movement, these small community unions, in sufficient numbers, could alter the political landscape and change the direction of current labor market policies. 
One such community center was established in the Indianapolis, Indiana area in 2012.

The Indianapolis Worker Justice Center provides outreach and information to low wage workers striving for better wages, benefits, working conditions, and dignity in the workplace by addressing such issues such as wage theft, unemployment and underemployment, misclassification, and immigration. Female hospitality workers in Indianapolis now have another resource for information and support as they strive to better their wages and working conditions.

\section{Conclusion}

Female pattern resistance strategies used by female housekeepers in the hospitality industry in two Midwestern hotels mirror those used by nineteenth century black enslaved females to thwart abuse, overwork, and sexual advances. Housekeepers and slaves find spaces within their respective work, social, and cultural environments to strategically resist, often in passive and non-compliant ways, the encroachment of the dominant and powerful to interfere with, disrupt, and reduce their leisure time, physical and mental well-being, self-esteem, and dignity. Through narrative forms, housekeepers and slaves tell their stories of oppression, abuse, devaluation, and exploitation not only to bring awareness to the broader public about their devalued and subordinate positions within a powerful oppressor/oppressed relationship but to engender changes through legitimate means to increase their rightful value and status within their employment relationship, their social and cultural environment, and their personal lives.

\section{Notes}

1. Lamphere \& Zavella. "Women's resistance".

2. Lawrence \& Robinson. "Ain't misbehaving”. 380.

3. Gordon. Power/knowledge.

4. Ibid.

5. Ong. Spirits of resistance.

6. Ibid. 203.

7. Ibid. 62 .

8. Ibid. 201-202. 
9. O’Neill. Illusion of consent. 3.

10. Pope. "Contract, race, and freedome". 1554.

11. Ibid.

12. Ibid. 1555 .

13. Ibid.

14. Ibid. 4556.

15. Glenn. "From servitude to service work".

16. Ibid. 1336

17. Jones. Labor of love. 15.

18. Ibid. 19.

19. Ibid. 16

20. Glenn. "From servitude to service work". 1336.

21. Tufts. "'We make it work".

22. Buchanan et al. "Occupational injury disparities".

23. Quigley. "We deserve better".

24. Sassen. Territory, authority, rights.

25. Ibid. 196.

26. Ibid. 197.

27. 1 bid. 9.

28. Glenn. "From servitude to service work". 1.

29. Braverman. Labour and monopoly capitalism. 271.

30. Glenn. "From servitude to service work".

31. Roberts. "Spiritual and menial housework".

32. Jones. Labor of love. 35.

33. Ibid. 35.

34. Ibid. 36.

35. Ibid. 36.

36. Adib \& Guerrier. "The interlocking of gender". 425.

37. Ibid.

38. Adkins. Gendered work.

39. Stanko. "Keeping women in".

40. Rodrigues \& Collinson. 'Having fun'.

41. Gabriel. "Beyond happy families". 22

42. Ibid. 192.

43. Pack. Literature, Language and Linguistics. 31.

44. Harley. "Speaking up".

45. Ibid. 47.

46. Smith. "The short overview". 33.

47. Braverman. Labor and monopoly capital.

48. Buroway. The politics of production.

49. Ibid. and Skorstad. Flexible organization.

50. Buroway. The politics of production. 45.

51. Ibid. 27

52. Benson. "Counter Cultures".

53. Hochschild. Farewell to the working class.

54. Brook. "In critical defense". 540. 
55. Ibid. 546.

56. Ibid. 539.

57. Buroway. Manufacturing consent.

58. Edwards \& Scullion. The social organization. 115.

59. Bolton. "Old ambiguities". 214.

60. Ibid.

61. Hochschild. Farewell to the working class.

62. Korczynski. "Communities of coping".

63. Hochschild. 114.

64. Korczynski. "Communities of coping". 58.

65. Ibid. 59.

66. Ibid. 73.

67. Ibid. 73.

68. Lamphere \& Zavella. "Women's resistance". 81.

69. Edwards, Collison, \& Della Rocca. Workplace resistance. 283.

70. Ong. Spirits of resistance.

71. Maich. "Feminist research and representations".

72. Deacon. Education as subjection. 117.

73. Maich. "Feminist research". 23.

74. Riessman. Narrative analysis.

75. Miles \& Huberman. Qualitative data analysis.

76. Riessman. Narrative analysis.

77. Ricoeur. Interpretation theory.

78. Blom \& Nygren. "Analysing written narratives".

79. Fleischner. Memory, family, and identity. 2.

80. Quigley. "We deserve better".

81. Bonanno. "Loss, trauma and human resilience"; Collins. "The relation of work stress"; Judkins. "Program evaluation".

82. Giordano. "Resilience: a survival tool". 1033.

83. Tusaie \& Dyer. "Resilience: a historical review". 4.

84. Jamieson. "Indianapolis hotel workers".

85. Maich. "Feminist research and representations".

86. Scott. Domination and the arts.

87. Ibid. 142.

88. Fleischner. Memory, family, and identity. 22.

89. Harley. "Speaking up." 31.

90. Fleischner. Memory, family, and identity. 4.

91. Ibid. 17.

92. Baumgartner. "The body as evidence." 255.

93. Fleischner. Memory, family, and identity. 4.

94. Girodano. "Resilience: a survival tool".

95. Jackson, Firtko, \& Edenborough. "Personal resilience".

96. Seifert \& Messing. "Cleaning Up After Globalization".

97. Quigley. "We deserve better".

98. Ibid. 
99. Buchanan et al. "Occupational injury disparities;" Burgel, Barbara J., White, Mary C., Gillen, Marion, \& Krause, Niklas. "Psychosocial factors;" Krause. "Physical workload". 100. Ibid.

101. Buchanan et al. "Occupational injury disparities". 118.

102. Ibid. 118.

103. Ibid. 118.

104. Baumgartner. "The body as evidence". 253.

105. Ibid. 254.

106. Ibid. 258.

107. Ibid. 260.

108. Ibid. 259.

109. Brodwin. "Symptoms and social performance".

110. Ortner. "Resistance". 187.

111. Brodwin. "Symptoms". 201.

112. Ibid. 201.

113. Scott. Domination and the arts. 701.

114. Kleinman. "Pain and resistance". 716.

115. Brodwin. "Symptoms and social performance"; Scott. Domination and the arts:

Kelinman. "Pain and resistance".

116. Doherty. "Harriet Jacobs' narrative strategies". 81.

117. Ibid. 82.

118. Fleischner. Memory, family, and identity. 5.

119. Fine. "Community unions".

120. Gorz. Farewell.

121. Fine. "Community unions".

\section{Bibliography}

Adib, Amel, and Guerrier, Yvonne. 2003. "The interlocking of gender with nationality, race, ethnicity and class: The narratives of women in hotel work." Gender, Work \& Organization 10 (4):413-432.

Baumgartner, Barbara. 2001. "The body as evidence: resistance, collaboration, and appropriation in The History of Mary Prince." Callaloo 24 (1):253-275.

Benson, Susan Porter. 1986. "Counter cultures: saleswomen, customers, and managers in American department stores, 1890-1940." Urbana and Chicago: University of Illinois Press.

Blom, Björn, and Nygren, Lennart. 2010. "Analysing written narratives: considerations on the 'codetotality problems'." Nordic Journal of Social Research 1.

Braverman, Harry. 1974. Labor and monopoly capital: The degradation of work in the twentieth century. New York: Monthly Review Press.

Brodwin, Paul. 1994. "Symptoms and social performance: the case of Diane Reden." In Pain as human expereince: An anthropological perspective, edited by Mary-JO D. Good, Brodwin, Paul E., Good, Bryon J., \& Kleinman, Arthur, 77-99. Berkley: University of California Press.

Brook, Paul 2009. "In critical defense of 'emotional labour': refuting Bolton's critique of Hoschschild's concept " Work, Employment \& Society 23:531-548. doi: 10.1177/0950017009337071.

Buchanan, Susan, Vossenas, Pamela, Krause, Niklas, Moriarty, Joan, Frumin, Eric, Shimek, Jo Anna M., Mirer, Franklin, Orris, Peter, and Punnett, Laura. 2010. "Occupational injury disparities in the US hotel industry." American Journal of Industrial Medicine 53 (2):116-125. doi:

10.1002/ajim.20724. 
Burgel, Barbara J. , White, Mary C., Gillen, Marion, \& Krause, Niklas. 2010. "Psychsocial work factors and shoulder pain in hotel room cleaners." American Journal of Industrial Medicine 53 (7):743-756. doi: 10.1002/ajim.20832.

Buroway, Michael. 1979. Manufacturing consent: Changes in the labor process under monopoly capitalism: University of Chicago Press.

Buroway, Micheal. 1985. The politics of production: Factory regimes under capitalism and socialism London: New Left Books.

Buroway, Micheal. 2008. "The public turn: from labor process to labor movement " Work and Occupations 35 (4):371-387.

Crosby, Faye J. 1987. "Sex and the workplace: the impact of sexual behavior and harassment on women, men, and organizations." In Psychology of Women Quarterly, edited by Gutek, Barbara, 130-132. San Francisco: Jossey-Bass.

Deacon, Roger \& Parker, Ben. 1995. "Education as subjection and refusal: an elabloration on Foucault." Curriculum Studies 3 (2):109-122.

Doherty, Thomas. 1985. "Harriet Jacobs' narrative strategies: 'Incidents in the life of a slave girl'." The Southern Literary Journal 19 (1):79-91.

Edwards, Paul, Collinson, David, \& Della Rocca, Giuseppe. 1995. "Workplace resistance in Western Europe: a preliminary overview and a research agenda." European Journal of Industrial Relations 1 (3):283-316. doi: 10.1177/095968019513001.

Edwards, Paul K. \& Scullion, Hugh. 1982. The social organization of industrial conflict : control and resistance in the workplace. Oxford Blackwell.

Fine, Janice. 2005. "Community unions and the revival of the American labor movement." Politics and Society 33:153-199.

Fleischner, Jennifer. 1996. Mastering slavery: Memory, family, and identity in women's slave narratives. Vol. 8: NYU Press.

Gabriel, Yiannis. 1999. "Beyond happy families: a critical reevaluation of the control-resistance-identity triangle." Human Relations 52 (2):179-203.

Giordano, Beverly P. 1997. "Resilience-a survival tool for the nineties." AORN journal 65 (6):10321034.

Glenn, Evelyn Nakano. 1992. "From servitude to service work: historical continuities in the racial division of paid reproductive labor." Signs:1-43.

Gordon, Colin, and Foucault, Michel. 1980. Power-knowledge: selected interviews and other writings, 1972-1977: Pearson Education.

Gorz, Andre. 1997. Farewell to the working class: an essay on post-industrial socialism: Pluto Press.

Harley, Sharon. 1997. "Speaking up: the politics of black women's labor history." Women and work: exploring race, ethnicity, and class:28-52.

Hochschild, Arlie 1983. The managed heart. Vol. 31. Berkeley, CA: University of California Press.

Jackson, Debra, Firtko, Angela, and Edenborough, Michel. 2007. "Personal resilience as a strategy for surviving and thriving in the face of workplace adversity: a literature review." Journal of Advanced Nursing 60 (1):1-9. doi: 10.1111/j.1365-2648.2007.04412.x.

Jamieson, Dan. 2012. "Indianapolis hotel workers settle lawsuit over wage theft allegations." Huffinton Post. http://www.huffingtonpost.com/2012/12/12/indianapolis-hotel-workerslawsuit n 2286046.html.

Jones, Jacqueline. 2009. Labor of love, labor of sorrow: black women, work, and the family, from slavery to the present: Basic Books.

Judkins, Sharon, Arris, Latonia, and Keener, Elizabeth. 2005. "Program evaluation in graduate nursing education: hardiness as a predictor of success among nursing administration students." Journal of Professional Nursing 21 (5):314-321. 
Kleinman, Arthur. 1992. "Pain and resistance: the delegitimation and relegitimation of local worlds "In Pain as human experience: an anthropoligical perspective, edited by Good, Mary-Jo D., Brodwin, Paul E., Good, Bryon, J., \& Kleinman, Authur. Berkley, CA: University of California Press.

Lamphere, Louise, Zavella, Patricia, and Gonzales, Felipe. 1993. Sunbelt working mothers: reconciling family and factory: Cornell University Press.

Lawrence, Thomas \& Robinson, Sandra 2007. "Ain't misbehavin: workplace deviance as organizational resistance." Journal of Management 33 (3):378-394.

Maich, Katherine. 2007. "Feminist Research and Representations of Gendered Service Workers." (the) future (of) feminisms:20.

Miles, Matthew, \& Huberman, Micheal. 1994. Qualitative data analysis : an expanded sourcebook. edited by Huberman, Micheal. Thousand Oaks Sage Publications.

O'Neill, Daniel, Shanley, Mary, and Young, Iris 2008. Illusion of Consent: engaging with Carole Pateman: Penn State Press.

Ong, Aihwa. 2010. Spirits of resistance and capitalist discipline: Factory women in Malaysia: Suny Press.

Ortner, Sherry B. 1995. "Resistance and the problem of ethnographic refusal." Comparative Studies in Society and History 37 (01):173-193.

Pack, Uraina. 2009. " 'Oh! The pity of it! In the land of the free and the home of the brave': Tricksterism and true womanhood in the slave narratives of Harriet Jacobs and Lucy Delaney " Journal of Literature, Language, and Linguistics 3 (1).

Pope, James Gray. 2010. "Contract, race, and freedom of labor in the constitutional Law of 'involuntary servitude'." The Yale Law Journal:1474-1567.

Quigley, Fran. 2012. We deserve better: hotel workers talking union. Nuvo, Indy's Alternative Voice.

Ricoeur, Paul. 1981. Hermeneutics and the human sciences : essays on language, action, and interpretation. edited by Thompson, John B. Cambridge [Eng.] Cambridge University Press

Riessman, Catherine Kohler. 1993. Narrative analysis. Newbury Park, CA Sage Publications.

Riessman, Catherine Kohler. 2008. Narrative methods for the human sciences. Los Angeles Sage Publications.

Roberts, D. 1997. "Spiritual and menial housework." Yale Journal of Law and Feminism 9:51-80.

Rodrigues, Suzana, and Collinson, David 1995. "'Having fun'?: humour as resistance in Brazil." Organization studies 16 (5):739-768.

Rodrigues, Suzana B, and Collinson, David L. 1995. "'Having fun'?: Humour as resistance in Brazil." Organization studies 16 (5):739-768.

Sassen, Saskia. 2006. Territory, authority, rights: from medieval to global assemblages. Vol. 4: Cambridge Univ Press.

Scott, James C. 1990. Domination and the arts of resistance: hidden transcripts: Yale University Press.

Seifert, Ana María, and Messing, Karen. 2006. "Cleaning up after globalization: an ergonomic analysis of work activity of hotel cleaners." Antipode 38 (3):557-578. doi: 10.1111/j.00664812.2006.00595.x.

Skorstad, Egil , and Ramsdal, Huge. 2009. "The ambiguity of flexibility." Flexible Organizations and the New Working Life: A European Perspective:17-42.

Smith, Chris. 2012. "The short overview of the labour process perspective and history of the International Labour Process Conference." International Labour Process Conference, Leeds.

Stanko, Elizabeth A. 1988. "Keeping women in and out of line: sexual harassment and occupational segregation." Gender Segregation at Work:91-99.

Tufts, Steven. 2006. "“We make it work": the cultural transformation of hotel workers in the city." Antipode 38 (2):350-373.

Tusaie Kathleen \& Dyer, Janyce. 2004. "Resilience: a historical review of the construct." Holistic Nursing Practice 18:3-10. 
